\title{
Antibiotic sensitivity against Xanthomonas axonopodis pv. citri by using Hi media disc
}

\author{
P.B. ABHANG ${ }^{1 *}$, A.A.WALUNJ ${ }^{2}$ AND M.V. TOTAWAR ${ }^{1}$
}

${ }^{1}$ Department of Plant Pathology, College of Agriculture, Loni, AHMEDNAGAR (M.S.) INDIA

${ }^{2}$ Department of Plant Pathology, Dr. Panjabrao Deshmukh Krishi Vidyapeeth, AKOLA (M.S.) INDIA

\section{ARITCLE INFO}

Received : 04.12 .2014

Revised : 19.01 .2015

Accepted : 03.02 .2015

\section{KEY WORDS :}

Xac, Himedia disc, Citrus canker, Antibiotics

*Corresponding author:

Email: preranaabhang09@gmail.com

\begin{abstract}
Citrus canker disease is of regular occurrence on several citrus cultivars in varying degrees of incidence depending on the climatic conditions. The bacterium, Xanthomonas causes different symptoms ranging from pustules to necrotic lesions consisting of erumpent corky tissue surrounded by water soaked tissues and yellow halo on leaves, stems and fruits. Sensitivity of different antibiotics were tested against Xanthomonas axonopodis pv. citri isolates (Xac). using eight different Hi-media disc viz., HX006, HX007, HX010, HX032, HX038, HX060, HX067, HX069. Each Hi-media disc having six different antibiotics of different concentration have been tested against Xacisolates. The causal pathogen Xanthomonas axonopodis pv. citri showed sensitivity to most of the antibiotic tested. Hi-media disc HX060 having antibiotic Imepenem (10mg) and Ticarcillin (70mg) showed maximum zone of inhibition (42mm). However, no effect of antibiotics i.e. Co-Trimoxazole, Nofloxacin, Cefoxitin, Erythromycin observed against Xac.
\end{abstract}

How to view point the article : Abhang, P.B., Walunj, A.A. and Totawar, M.V. (2015). Antibiotic sensitivity against Xanthomonas axonopodis pv. citri by using Hi media disc. Internat. J. Plant Protec., 8(1) : 53-56. 